\title{
Familial defective apolipoprotein B-100 in a group of hypercholesterolaemic patients in Poland. Identification of a new mutation $\mathrm{Thr}_{3492}$ lle in the apolipoprotein B gene
}

Małgorzata Bednarska-Makaruk*,1, Mariola Bisko ${ }^{1}$, Maria F Puławska ${ }^{2}$, Dorota Hoffman-Zacharska ${ }^{1}$, Maria Rodo ${ }^{1}$, Marta Roszczynko ${ }^{2}$, Alicja Solik-Tomassi ${ }^{4}$, Grażyna Broda ${ }^{3}$, Maria Polakowska ${ }^{3}$, Aleksandra Pytlak ${ }^{3}$ and Hanna Wehr ${ }^{1}$

${ }^{1}$ Department of Genetics, Institute of Psychiatry and Neurology, Warsaw, Poland; ${ }^{2}$ Department of Clinical Biochemistry, National Institute of Cardiology, Warsaw, Poland; ${ }^{3}$ Department of Epidemiology and Prevention of Cardiovascular Disease, National Institute of Cardiology, Warsaw, Poland; ${ }^{4}$ Outpatient Clinic, National Institute of Cardiology, Warsaw, Poland

The prevalence of the familial defective apolipoprotein B-100 (FDB) Arg $_{3500}$ Gln mutation in 525 unrelated hypercholesterolaemic Polish subjects was evaluated. DNA samples were screened for FDB mutation using SSCP method. Presence of mutation was confirmed using a mismatch MspI PCR strategy. Plasma lipid levels and clinical characteristics of 13 patients identified as carriers of the mutation and of their 23 affected relatives were analysed and compared with non-affected ones. In the affected individuals a variable expression of lipid concentrations and of atherosclerosis symptoms were observed. The prevalence of FDB $\operatorname{Arg}_{3500} \mathrm{Gln}$ mutation in hypercholesterolaemic Polish subjects (3.7\%) seems to be similar to the frequency reported in other Caucasian hypercholesterolaemic populations. The estimated prevalence of the mutation in general Polish population is relatively high being $1 / 250$. The same haplotype at the apoB locus in the carriers of this mutation in Poland as in other populations from Western Europe suggests its common origin. In one hypercholesterolaemic subject a non-hitherto described mutation was identified. It consisted in $\mathrm{C} \rightarrow \mathrm{T}$ transition in apoB codon 3492 leading to threonine to isoleucine substitution in $\mathbf{3 4 9 2}$ position of apoB gene ( $\mathrm{Thr}_{3492}$ Ile). European Journal of Human Genetics (2001) 9, 836-842.

Keywords: Familial defective apolipoprotein B-100 (FDB); prevalence in Poland; new mutation

\section{Introduction}

Familial defective apolipoprotein B-100 (FDB) is an autosomal dominantly inherited genetic disease first described by Innerarity et al $^{1}$ and characterised by hypercholesterolaemia and premature atherosclerosis.

*Correspondence: M Bednarska-Makaruk, Institute of Psychiatry and Neurology, Department of Genetics, ul. Sobieskiego 1/9, 02-957 Warszawa, Poland. Tel: (+48) (22) 84276 50; Fax: (+48) (22) 85891 69; E-mail: makaruk@ipin.edu.pl

Received 27 July 2001; revised 16 August 2001; accepted 19 August 2001
Apo B-100 is the only protein of low density lipoproteins (LDL) and its binding to the LDL receptor is essential for the normal removal of LDL from plasma. The disorder is characterised by clinical and lipoprotein abnormalities very similar to familial hypercholesterolaemia caused by the LDL receptor deficiency. ${ }^{2,3}$ Recently numerous authors report that the symptoms in FDB are less severe than in disease caused by LDL receptor mutations. ${ }^{4-7}$

The most common mutation in FDB is an adenine for guanine substitution in complementary DNA of exon 26 of apo B gene. It results in an arginine for glutamine change in the 3500 amino acid position of the protein. ${ }^{8}$ The mutation 
strongly reduces protein binding by the receptor. The occurrence of other kinds of mutations was also reported most of them very rare. They are either localised in the same 3500 site - $\left(\operatorname{Arg}_{3500} \operatorname{Trp}\right)^{9}-$ or in its close proximity $\left(\operatorname{Arg}_{3531}\right.$ Cys $) .{ }^{10}$

FDB has been identified basing on DNA analysis in Caucasian populations of North America and in numerous European countries with a frequency ranging from 1:210 to 1:1250. It was however not found in Finland, Spain, Russia and Japan. ${ }^{11-14}$

The vast majority of the individuals carrying the apo B $\operatorname{Arg}_{3500}$ Gln mutation has an identical apo B haplotype which strongly suggests that the mutation occurred on a single ancestral gene. ${ }^{11,15}$ Only a few independent mutations ie, accompanied by other haplotypes were described. ${ }^{14}$

Five families carrying the apo B Arg3500Gln mutation were recently described in Poland. ${ }^{16}$

In the present study the frequency of the FDB $\operatorname{Arg}_{3500} \mathrm{Gln}$ mutation in 525 unrelated hypercholesterolemic Polish subjects was evaluated.

\section{Subjects}

Five hundred and twenty-five unrelated patients (309 men and 216 women) with moderate and severe hypercholesterolaemia (LDL cholesterol $\geqslant 160 \mathrm{mg} / \mathrm{dl}$ ), aged $20-82$ years (mean age $57.5 \pm 9.7$ years) recruited from the outpatient lipid clinic of the National Institute of Cardiology in Warsaw, Poland, were screened by single-strand conformation polymorphism (SSCP) analysis for the presence of FDB mutation. 351 (206 men and 145 women) had primary type IIA hyperlipoproteinaemia (HLP IIA) (triglycerides $<200 \mathrm{mg} /$ dl) and 174 of them (103 men and 71 women) had type IIB hyperlipoproteinaemia (HLP IIB) (triglycerides $\geqslant 200 \mathrm{mg} / \mathrm{dl}$ but $<400 \mathrm{mg} / \mathrm{dl}$ ). Sixty-five patients ( 42 men and 23 women) from HLP IIA group could be diagnosed as familial hypercholesterolaemia $\left(\mathrm{FH}_{\mathrm{clin}}\right)$ basing on the clinical criteria according to Study Group European Atherosclerosis Society ${ }^{17}$ ie, LDL cholesterol level above $190 \mathrm{mg} / \mathrm{dl}$ and the presence of tendon xanthomas in the patient or in a first-degree relative.

Seventy available relatives and 12 spouses of identified probands were subsequently investigated.

The study was approved by the Ethics Committee of National Institute of Cardiology. All the participants gave their informed consent for the investigation.

\section{Methods}

Blood samples were obtained after an overnight fast. Lipid levels were determined either before starting hypolipaemic therapy or after the period of at least 6 weeks without treatment. Total serum cholesterol (TC) and triglycerides (TG) were determined by enzymatic assays (Boehringer Mannheim). High density lipoprotein cholesterol (HDL-C) was determined after precipitation of apo B-100 containing lipoproteins. LDL cholesterol (LDL-C) concentration was calculated according to Friedewald formula. Lipoprotein(a) $[\mathrm{Lp}(\mathrm{a})]$ concentration was measured by electroimmunodiffusion (Sebia).

Genomic DNA was obtained from the white blood cells by phenol/chloroform extractions and ethanol precipitation according to Maniatis. ${ }^{18}$

A $320 \mathrm{bp}$ fragment of the apo B gene was amplified with oligonucleotides UOL and LOL as described by Schuster et $a l^{19}$ using GeneAmp PCR System 2400 (Perkin-Elmer Corp., Norwalk, Connecticut, USA). PCR product was screened for the presence of FDB mutation by single-strand conformation polymorphism (SSCP) analysis according to Chaves et al ${ }^{20}$ with minor modifications. A mixture consisting of $5 \mu \mathrm{l}$ of PCR product and $5 \mu \mathrm{l}$ of formamide was heated for $5 \mathrm{~min}$ at $95^{\circ} \mathrm{C}$ and then plunged into ice prior to loading onto the $12 \%$ acrylamide (50:1 acrylamide:bisacrylamide) gel with 5\% glycerol. Electrophoresis was carried out at $200 \mathrm{~V}$ for $5 \mathrm{~h}$ at $4^{\circ} \mathrm{C}$. After electrophoresis the gels were stained with silver. As positive controls, DNA from Dutch and German patients heterozygous for the FDB $\mathrm{Arg}_{3500} \mathrm{Gln}$ mutation were used.

The presence of $\operatorname{Arg}_{3500} \mathrm{Gln}$ mutation was confirmed using a mismatch MspI PCR modified strategy as described by Motti $^{21}$ with modifications of Defesche ${ }^{3}$ (and personal communication) and our own minor changes (instead of carrying out a hot start prior to addition of the Taq polymerase, AmpliTaq Gold DNA polymerase (Perkin-Elmer Corp.) was used and therefore the number of PCR cycles was increased to 35). A $477 \mathrm{bp}$ fragment (final PCR product was 517 bp because of the 40 base long CG clamp at the $5^{\prime}$ end of the $5^{\prime}$-primer) of exon 26 of the apo $\mathrm{B}$ gene was amplified using oligonucleotides Apo-B-5 and Apo-B-3. After an initial denaturation step at $95^{\circ} \mathrm{C}$ for $5 \mathrm{~min}$, reaction was carried out for 35 cycles of amplification as follows: denaturation at $95^{\circ} \mathrm{C}$ for $1 \mathrm{~min}$, annealing at $60^{\circ} \mathrm{C}$ for $1 \mathrm{~min}$, and extension at $72^{\circ} \mathrm{C}$ for $2 \mathrm{~min}$. A final extension at $72^{\circ} \mathrm{C}$ for $7 \mathrm{~min}$ was also performed. Twenty-five $\mu \mathrm{l}$ of reaction mixture was digested by the restriction endonuclease MspI (Amersham Life Science), using the conditions recommended by manufacturer. Digestion products were separated by electrophoresis at room temperature on $2 \%$ agarose gels, stained with ethidium bromide and viewed over ultra violet light.

Sequencing was performed in DNA samples from the individual with atypical mutation (P132) and from a normal control. Exon 26 was amplified by polymerase chain reaction using oligonucleotide primers UOL and LOL and reaction conditions as described before. The products were purified using a Qiagen polymerase chain reaction kit and sequenced manually using the Thermo Sequenase Cycle Sequencing Kit (Amersham Life Science) under conditions recommended by the manufacturer.

Three biallelic markers were analysed to establish haplotypes at the apo B locus. The RFLPs of $X b a \mathrm{I},{ }^{22} \mathrm{MspI}^{8}$ in exon 26 and $E c o \mathrm{RI}^{15}$ in exon 29 were determined. The MspI RFLP was also confirmed by the technique used for the detection of 
FDB $\operatorname{Arg}_{3500}$ Gln mutation as described earlier. Construction of the haplotypes was based on the assumption that there had been no recombination event within the apo $B$ gene.

Genotype of apolipoprotein E was identified using the method of Hixson and Vernier. ${ }^{23}$

\section{Statistical analysis}

Prevalence estimates of the mutation were expressed as percentages with 95\% confidence intervals. Data for quantitative variables were expressed as mean values \pm SD. $L p(a)$ concentrations were expressed also as median values. Differences in means between FDB and non-FDB subjects were tested by the Mann-Whitney two-sample test. The lipid results were also adjusted by sex, age and family-connection using analysis of covariance. Statistical significance of the differences in the frequencies of the apo E alleles and of other qualitative variables was evaluated using $\chi^{2}$ or Fisher exact test. $P$-values lower than 0.05 were considered as statistically significant.

\section{Results}

SSCP screening of the whole group of 525 hypercholesterolaemic patients resulted in an initial identification of FDB mutation in 14 individuals. All the patients belonged to the HLP IIA group. The mutation was not found in any of 174 patients with HLP IIB. In one patient (P132) the SSCP pattern differed slightly from the patterns characteristic for both positive and negative results (Figure 1). In all but this one person with the atypical SSCP pattern the presence of the $\operatorname{Arg}_{3500}$ Gln mutation has been confirmed by the mismatch MspI PCR method. All of them were heterozygous for the mutation.

The calculated prevalence of the $\operatorname{Arg}_{3500}$ Gln mutation was $2.5 \%$ in the whole hypercholesterolaemic group and $3.7 \%$ in the IIA type HLP group. In 65 patients with the clinical characteristics of familial hypercholesterolaemia $\left(\mathrm{FH}_{\text {clin }}\right)$ the frequency can be evaluated as $10.8 \%$ (Table 1 ).

In the patient P132 with atypical SSCP pattern and non confirmed $\mathrm{Arg}_{3500} \mathrm{Gln}$ mutation further investigations by DNA sequencing revealed another kind of mutation in the same region of the apo B gene. A $\mathrm{C} \rightarrow \mathrm{T}$ transition in codon 3492 $(\mathrm{ACT} \rightarrow \mathrm{ATT})$ which is producing a change from threonine to isoleucine in the encoded amino acid sequence was found $\left(\mathrm{Thr}_{3492}\right.$ Ile) (Figure 2). Such mutation was not described before. The patient was heterozygous for the mutation.

Table 2 presents the clinical and biochemical characteristics of 14 probands with both mutations. Out of 13 subjects with the $\operatorname{Arg}_{3500}$ Gln FDB mutation, eight had coronary artery disease (CAD) and two peripheral artery disease (PAD) symptoms and in four of them tendon xanthomas were found. The patient with $\mathrm{Thr}_{3492}$ Ile mutation was highly hypercholesterolaemic, had first symptoms of angiographically confirmed CAD at the age of 39 years as well as angiographically confirmed PAD at the age of 38 years and had tendon xanthomatosis. All

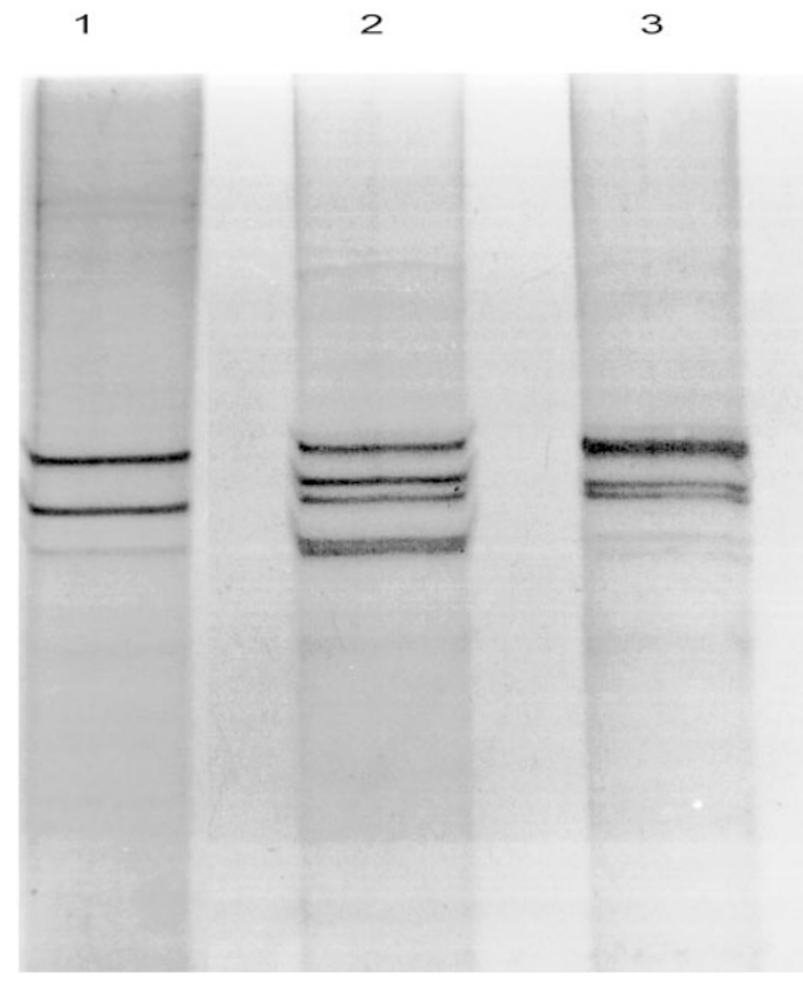

Figure 1 DNA screening for FDB mutation by SSCP analysis of PCR products. Lane 1, unaffected individual; Lane 2, subject heterozygous for $\operatorname{Arg}_{3500}$ Gln mutation; Lane 3, atypical SSCP pattern in P132 proband heterozygous for the new $\operatorname{Trp}_{3492}$ lle mutation.

investigated relatives ie, his two sons and brother were carriers of the mutation, but their total and LDL cholesterol were not elevated. The brother of the proband had the first symptoms of angiographically confirmed CAD at the age of 50 years. Both sons (still young - 20 and 22 years) were asymptomatic. The father of the proband died at the age of 73 years because of the third myocardial infarction (his first MI was at the age of 40 years).

Haplotype analysis of 10 families with FDB $\operatorname{Arg}_{3500} \mathrm{Gln}$ mutation demonstrated that the mutant allele segregated with the haplotype $X b a I^{-} / M_{p} \mathrm{I}^{+} / E c o \mathrm{RI}^{-}$. The lack of DNA from family members of two probands (P82 and P537) and non-informative family pedigrees of another proband (P526) precluded unambiguous resolution of their haplotypes. Analysis of probands genotype (Table 2) showed however that one of the two alleles could also represent the $\mathrm{XbaI}^{-}$/ $\mathrm{MspI}^{+} /$EcoRI ${ }^{-}$haplotype.

A comparison of the results of lipid and lipoprotein determinations and of clinical characteristics in 36 FDB subjects (13 probands and their affected relatives) with 44 non-FDB relatives is shown in Table 3 . The carriers of the $\operatorname{Arg}_{3500}$ Gln mutation had markedly higher mean TC and LDL-C levels. The median Lp(a) level was similar in both groups, but in 
Table 1 The prevalence of FDB in hypercholesterolaemic patients

\begin{tabular}{|c|c|c|c|c|c|c|c|}
\hline & $\begin{array}{l}\text { Number of } \\
\text { subjects }\end{array}$ & \multicolumn{3}{|c|}{$\begin{array}{l}\text { Frequency of FDB mutation } \\
\text { (screening-SSCP analysis) }\end{array}$} & \multicolumn{3}{|c|}{$\begin{array}{l}\text { Frequency of } \operatorname{Arg}_{3500} \text { Gln mutation } \\
\text { (confirmation by mismatch Mspl PCR) }\end{array}$} \\
\hline Type IIA hyperlipoproteinaemia & 351 & 14 & 4.0 & $(1.0-6.0)$ & $13^{\mathrm{a}}$ & 3.7 & $(1.7-5.8)$ \\
\hline - $\mathrm{FH}_{\text {clin }}$ & 65 & 7 & 10.8 & $(3.2-18.3)$ & 7 & 10.8 & $(3.2-18.3)$ \\
\hline - non-FH & 286 & 7 & 2.4 & $(0.66-4.2)$ & 6 & 2.1 & $(0.43-3.8)$ \\
\hline
\end{tabular}

${ }^{a}$ One patient (P132) screened for FDB by SSCP shows a pattern slightly differing both from other FDB individuals and nonaffected subjects. The apo B-100 Arg $_{3500}$ Gln mutation was not confirmed using the mismatch Mspl PCR. This subject was a carrier of another hitherto nondescribed $\left(\mathrm{Thr}_{3492} \mathrm{lle}\right)$ mutation in the same region of apo B-100 gene identified by sequencing of this DNA fragment.

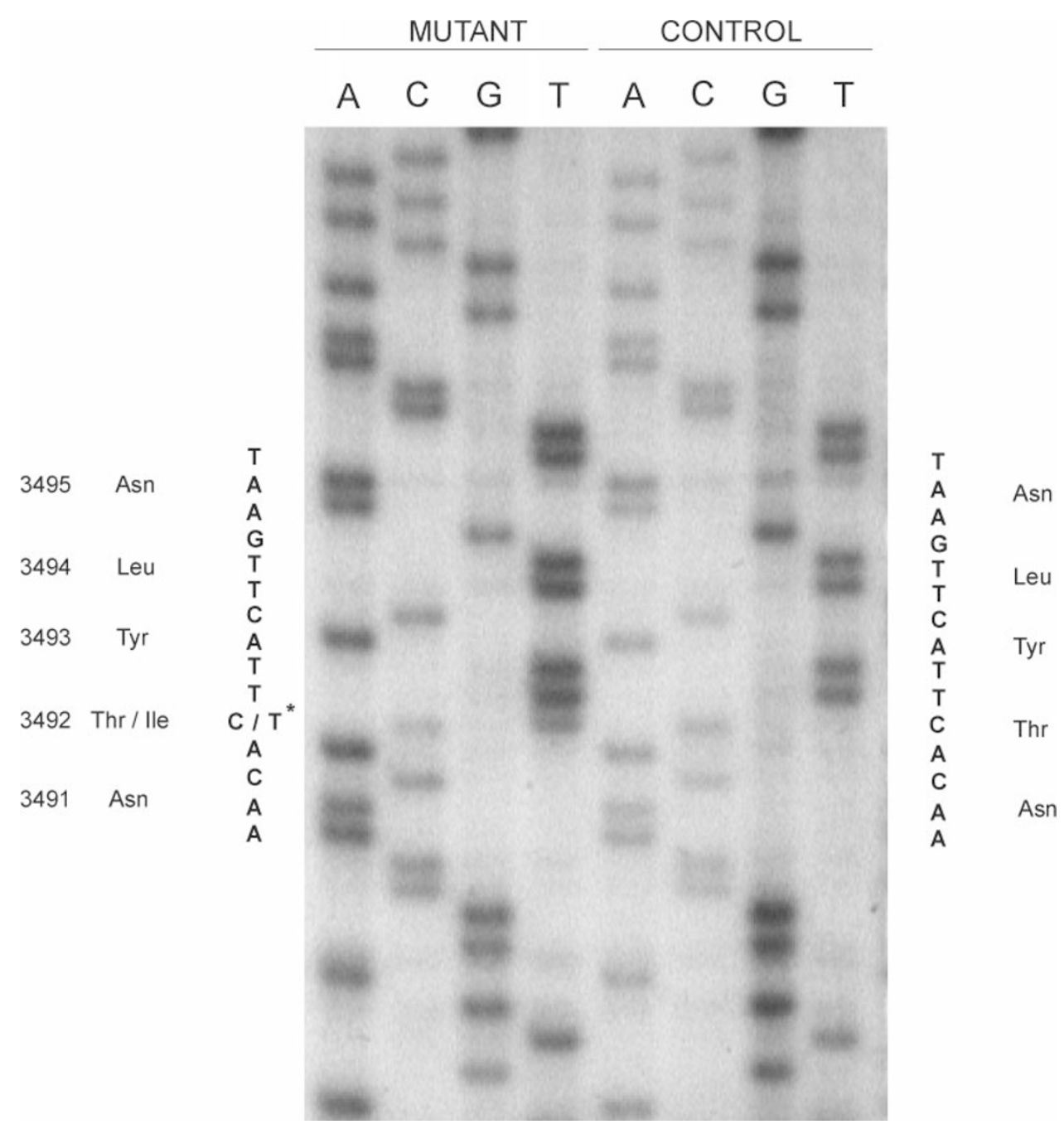

Figure 2 Autoradiograph of the $6 \%$ polyacrylamide gel, showing the nucleotide sequences of amplified double-stranded DNA fragment of exon 26 of the apo B gene from the patient P132 with atypical SSCP pattern (mutant) and from normal control.

affected subjects Lp(a) level above $30 \mathrm{mg} / \mathrm{dl}$ occurred more frequently than in nonaffected ones $(31.4 \%$ vs $16.3 \%$, respectively). $22.6 \%$ of adult FDB subjects (above 20 years of age) had tendon xanthomas. Cardiovascular disease as defined by angina or history of MI was present in $38.7 \%$ of the adult FDB subjects as compared with $10.3 \%$ in their non-FDB relatives. 
Table 2 Clinical and biochemical characteristics of probands with $\operatorname{Arg}_{3500} G$ ln mutation causing FDB and proband with new mutation $\mathrm{Thr}_{3492}$ lle

\begin{tabular}{|c|c|c|c|c|c|c|c|c|c|c|c|c|c|c|}
\hline $\begin{array}{l}\text { Proband } \\
\text { No }\end{array}$ & Sex & $\begin{array}{l}\text { Age } \\
\text { at DNA } \\
\text { analysis } \\
\text { (years) }\end{array}$ & $\begin{array}{l}\text { Age at lipid } \\
\text { measurement } \\
\text { (years) }\end{array}$ & Mutation & $\begin{array}{l}\text { Haplo } \\
\text { Xbal }\end{array}$ & $\begin{array}{l}\text { type } n \\
\text { Msp/ }\end{array}$ & $\begin{array}{l}\text { narker } \\
\text { EcoRI }\end{array}$ & $\begin{array}{c}T C \\
(m g / d l)\end{array}$ & $\begin{array}{l}L D L-C \\
(m g / d l)\end{array}$ & $\begin{array}{l}H D L-C \\
(m g / d l)\end{array}$ & $\begin{array}{c}T G \\
(m g / d l)\end{array}$ & $\begin{array}{l}\operatorname{Lp}(a) \\
(m g / d l)\end{array}$ & $\begin{array}{c}\text { ApoE } \\
\text { genotype }\end{array}$ & $\begin{array}{l}\text { Clinical findings } \\
\text { (age, years) }\end{array}$ \\
\hline P161 & $\mathrm{M}$ & 46 & 43 & $\operatorname{Arg}_{3500} \mathrm{Gln}$ & $-1-$ & $+/+$ & $+1-$ & 301 & 211 & 79 & 56 & 48 & $3 / 3$ & $\mathrm{MI}(38), \mathrm{CABG}$ \\
\hline P165 & $\mathrm{M}$ & 64 & 60 & $\operatorname{Arg}_{3500} \mathrm{Gln}$ & $+1-$ & $+/+$ & $+1-$ & 398 & 327 & 48 & 113 & 13 & $3 / 3$ & MI (54), CABG, PAD \\
\hline P186 & $\mathrm{M}$ & 59 & 56 & $\mathrm{Arg}_{3500} \mathrm{Gln}$ & $+1-$ & $+/+$ & $+1-$ & 295 & 225 & 42 & 140 & 10 & $4 / 3$ & CAD (50), CABG \\
\hline P432 & $M$ & 43 & 44 & $\operatorname{Arg}_{3500} \mathrm{Gln}$ & $-1-$ & $+/+$ & -1 & 298 & 230 & 45 & 114 & 12 & $3 / 3$ & $\begin{array}{c}\text { CAD (38), MI (39), } \\
\text { PCTA }\end{array}$ \\
\hline P526 & $\mathrm{F}$ & 31 & 21 & $\operatorname{Arg}_{3500} \mathrm{Gln}$ & $+1-$ & $+/-$ & $+1-$ & 316 & 236 & 57 & 113 & 37 & $3 / 3$ & $\mathrm{XT}$ \\
\hline P537 & $\mathrm{F}$ & 61 & 55 & $\operatorname{Arg}_{3500} \mathrm{Gln}$ & $-1-$ & $+/+$ & $+1-$ & 371 & 283 & 61 & 134 & NA & $2 / 3$ & XT \\
\hline P668 & $\mathrm{F}$ & 60 & 59 & $\operatorname{Arg}_{3500} \mathrm{Gln}$ & $+1-$ & $+/+$ & $+1-$ & 347 & 278 & 56 & 147 & 102 & $4 / 3$ & $\begin{array}{c}\text { CAD (41), MI (49), } \\
\text { PAD, HT }\end{array}$ \\
\hline
\end{tabular}

$\mathrm{M}$, male; $\mathrm{F}$, female; $\mathrm{CAD}$, coronary artery disease; $\mathrm{MI}$, myocardial infarction; $\mathrm{CABG}$, coronary artery bypass graft; PAD, peripheral artery disease; $\mathrm{HT}$, hypertension; XT, tendon xanthomas; NA, no data available.

Table 3 Comparison of FDB ( $\operatorname{Arg}_{3500}$ Gln mutation) subjects and their non-FDB relatives

\begin{tabular}{|c|c|c|c|c|c|c|c|c|}
\hline & & $\begin{array}{r}F D B(\mathrm{n}=36) \\
\text { Adjusted mean }\end{array}$ & Range & & $\begin{array}{l}\text { non-FDB }(\mathrm{n}=44 \\
\text { Adjusted mean }\end{array}$ & Range & $P$ & $P^{b}$ \\
\hline $\operatorname{Sex}(M / F)$ & $18 / 18$ & & & $18 / 26$ & & & ns & \\
\hline Age, mean $\pm S D$ (years) & $44.3 \pm 18.6$ & & $(7-77)$ & $32.7 \pm 20.2$ & & $(6-74)$ & 0.0109 & \\
\hline $\mathrm{TC}$, mean $\pm \mathrm{SD}(\mathrm{mg} / \mathrm{dl})$ & $288 \pm 57.1$ & 280.7 & $(149-398)$ & $200 \pm 51.0$ & 207.3 & $(116-330)$ & $<0.0001$ & $<0.0001$ \\
\hline $\mathrm{LDL}-\mathrm{C}$, mean $+\mathrm{SD}(\mathrm{mg} / \mathrm{dl})$ & $212+53.2$ & 204.1 & $(86-327)$ & $118+45.3$ & 124.9 & $(45-213)$ & $<0.0001$ & $<0.0001$ \\
\hline HDL-C, mean \pm SD (mg/dl) & $52 \pm 12.0$ & 53.4 & $(34-81)$ & $56 \pm 13.0$ & 55.0 & $(30-89)$ & ns & ns \\
\hline $\mathrm{TG}$, mean $\pm \mathrm{SD}(\mathrm{mg} / \mathrm{dl})$ & $136 \pm 92.4$ & 131.9 & $(55-552)$ & $120 \pm 74.7$ & 123.8 & $(35-450)$ & ns & ns \\
\hline $\operatorname{Lp}(\mathrm{a}), \operatorname{me} \bar{n} \pm S D(\mathrm{mg} / \mathrm{dl})$ & $34.4 \pm 43.7$ & 32.4 & $(<5-140)$ & $19.4 \pm 29.9$ & 21.4 & $(<5-140)$ & 0.077 & ns \\
\hline $\begin{array}{l}\mathrm{Lp}(\mathrm{a}), \text { median }(\mathrm{mg} / \mathrm{dl}) \\
\quad \text { percentyl }(25-75)(\mathrm{mg} / \mathrm{dl})\end{array}$ & $\begin{array}{c}12 \\
6.5-41\end{array}$ & & & $\begin{array}{c}9 \\
<5-16\end{array}$ & & & ns & \\
\hline $\mathrm{Lp}(\mathrm{a})>30 \mathrm{mg} / \mathrm{dl}(\%)$ & 31.4 & & & 16.3 & & & ns & \\
\hline \multicolumn{9}{|l|}{ Apo E allele } \\
\hline$\varepsilon 2(\%)$ & 4.3 & & & 8.1 & & & ns & \\
\hline$\varepsilon 3(\%)$ & 78.6 & & & 75.6 & & & ns & \\
\hline$\varepsilon 4(\%)$ & 17.1 & & & 16.3 & & & ns & \\
\hline CAD $(\geqslant 20$ years $)(\%)$ & 38.7 & & & 10.3 & & & 0.0164 & \\
\hline Age of CAD onset, mean $\pm S D$ (years) & $47.6 \pm 8.7$ & & ( $37-62$ years) & $52.3 \pm 6.1$ & & (47-59 years) & ns & \\
\hline $\mathrm{Ml}(\geqslant 20$ years $)(\%)$ & 25.8 & & (38-51 years) & $3 . \overline{4}$ & & (59 years) & 0.0265 & \\
\hline $\mathrm{XT}(\geqslant 20$ years $)(\%)$ & 22.6 & & & 0 & & & 0.0109 & \\
\hline
\end{tabular}

${ }^{\mathrm{a}}$ Means adjusted for age, sex and family connection; ${ }^{\mathrm{b}} \mathrm{p}$ after adjustment of means for age, sex and family connection; CAD, coronary artery disease; MI, myocardial infarction; XT, tendon xanthomas.

Comparison of lipid and lipoprotein levels in affected and non-affected family members showed some degree of overlapping of the results. Four young FDB mutation carriers had LDL-C in normal or in the upper range of normal levels. Two diabetic FDB patients had also hypertriglyceridaemia. Some non-FDB relatives and spouses showed lipid abnormalities: mostly mild or moderate hypercholesterolaemia, and some of them mild hypertriglyceridaemia.
Lipid and lipoprotein levels did not differ significantly between FDB patients carriers of various apolipoprotein $\mathrm{E}$ allele (data not shown).

\section{Discussion}

In this study Polish unrelated individuals with moderate and severe hypercholesterolaemia were screened for the presence of the FDB $\operatorname{Arg}_{3500}$ Gln mutation. The mutation was detected 
only in type IIA hypercholesterolaemic patients. Its frequency was $3.7 \%$. The prevalence of FDB $\operatorname{Arg}_{3500} \mathrm{Gln}$ mutation in the investigated group was similar to the frequency $(1-6 \%)$ observed in hypercholesterolaemic subjects from other Caucasian populations of Western Europe, North America and Australia. ${ }^{14,24}$

In the present study all FDB heterozygotes were identified among individuals classified as having either clinical symptoms of $\mathrm{FH}(10.8 \%)$ or type IIA HLP without FH symptoms $(2.1 \%)$. Our sample of hypercholesterolaemic patients containing a relatively high number of probably FH subjects is not representative of the general population. A crude estimate of the frequency of the $\operatorname{Arg}_{3500}$ Gln mutation in Polish population can be made based on the frequency of hypercholesterolaemia ( $>250 \mathrm{mg} / \mathrm{dl}$, without hypertriglyceridaemia) in Poland evaluated as approximately 19\% (data from Pol-MONICA Warsaw Program ${ }^{25}$ - 1519 individuals, age 35-64, screened in 1993 as the part of international WHO-MONICA Project). Assuming the frequency of FH in general population of $1 / 500(0.2 \%),{ }^{26}$ an estimate of the frequency of the $\operatorname{Arg}_{3500}$ Gln mutation in Polish population was $10.8 \% \times 0.2 \%$ plus $2.1 \% \times(19 \%-0.2 \%) \approx 1 / 250$.

In our study relatively high frequency $(10.8 \%)$ of the mutation was found among clinically diagnosed FH patients. In most other studies based on the same clinical criteria FDB frequency in this group was reported to be $2-3 \% .{ }^{14,24} \mathrm{~A}$ higher frequency $(12 \%)$ was stated only in Switzerland. ${ }^{5}$ Recently in Poland FDB mutation was found in five of 30 families (17\%) with clinical signs of familial hypercholesterolaemia. ${ }^{16}$ It suggests that FDB mutation may be a rather frequent cause of clinically recognised familial hypercholesterolaemia in Poland.

Comparison of the lipid parameters in FDB subjects and their non-FDB relatives (in which environmental and other genetic factors were similar) revealed that cholesterol concentration was not fully informative for FDB diagnosis as TC and LDL-C concentrations in subjects with and without mutation were overlapping to some extent. Such observations were also noted in other studies. ${ }^{4,6,27}$ DNA analysis in the relatives of FDB mutation carriers should therefore be strongly recommended as a method of an early identification of other carriers.

In one of the examined hypercholesterolaemic patients a new mutation was detected. It was localised in codon 3492 of the apo B gene causing threonine to isoleucine substitution. The patient-carrier of this mutation was hypercholesterolaemic and had symptoms of premature atherosclerosis in coronary and peripheral arteries, tendon xanthomatosis and family history of premature atherosclerosis. All investigated relatives of the proband were carriers of the mutation and all were normocholesterolaemic. However as it was observed for the $\mathrm{Arg}_{3500} \mathrm{Gln}$ mutation, the TC and LDL-C concentrations might be not fully informative for FDB diagnosis. The $\mathrm{Thr}_{3492}$ Ile mutation is situated in close proximity of the typical $\operatorname{Arg}_{3500} \mathrm{Gln}$ one. To determine the influence of this mutation on the apo B-100 ligand function, the study of binding affinity of proband's LDL to LDL receptor is necessary.

A high prevalence of another kind of apo B mutation - the $\operatorname{Arg}_{3531}$ Cys mutation was recently stated in Denmark ${ }^{7}$ and in France. ${ }^{28}$ The frequency of this kind of mutation in Poland has not yet been established.

In summary, our study showed that the prevalence of the $\operatorname{Arg}_{3500}$ Gln mutation in Polish hypercholesterolaemic patients was $3.7 \%$ which was similar to the frequency detected in hypercholesterolaemic groups in several other European countries. The estimated prevalence of the mutation in the general Polish population could be relatively high $-1 / 250$. The same haplotype at the apo $\mathrm{B}$ locus in the carriers of this mutation in Poland suggests its common origin with other populations from Western Europe. A not hitherto reported kind of mutation in apo B gene - a $\mathrm{Thr}_{3492}$ Ile mutation was found in one hypercholesterolaemic subject with early CAD symptoms. The determination of the influence of the mutation on LDL binding to LDL receptor is necessary.

\section{Acknowledgments}

This work was supported by grant No 4 P05D 03809 from the Komitet Badań Naukowych, Poland. DNA from a Dutch patient heterozygous for the FDB Arg 3500 Gln mutation and Apo-B-5 and Apo$B-3$ primers and the description of the mismatch MspI PCR method were kindly supplied by JC Defesche, PhD, Amsterdam, The Netherlands. DNA from a German patient heterozygous for the FDB $\mathrm{Arg}_{3500} \mathrm{Gln}$ mutation was the gift from Prof H Schuster, Berlin, Germany.

\section{References}

1 Innerarity TL, Weisgraber KH, Arnold KS et al: Familial defective apolipoprotein B-100: low density lipoproteins with abnormal receptor binding. Proc Natl Acad Sci USA 1987; 84: 6919-6923.

2 Tybjaerg-Hansen A, Gallagher J, Vincent J et al: Familial defective apolipoprotein B-100: detection in the United Kingdom and Scandinavia, and clinical characteristics of ten cases. Atherosclerosis 1990; 80: 235-242.

3 Defesche JC, Pricker CL, Hayden MR, van der Ende BE, Kastelein JJP: Familial defective apolipoprotein B-100 is clinically undistinguishable from familial hypercholesterolemia. Arch Int Med 1993; 153: $2349-2356$.

4 Gallagher JJ, Myant NB: Variable expression of the mutation in familial defective apolipoprotein B-100. Arterioscler Thromb 1993; 13: $973-976$.

5 Miserez AR, Keller U: Differences in the phenotypic characteristics of subjects with familial defective apolipoprotein B-100 and familial hypercholesterolemia. Arterioscler Thromb Vasc Biol 1995; 15: 1719-1729.

6 Pimstone SN, Defesche JC, Clee SM, Bakker HD, Hayden MR, Kastelein JJP: Differences in the phenotype between children with familial defective apolipoprotein B-100 and familial hypercholesterolemia. Atrerioscler Thromb Vasc Biol 1997; 17: $826-833$.

7 Tybjaerg-Hansen A, Steffensen R, Meinertz H, Schnohr P, Nordestgaard BG: Association of mutations in the apolipoprotein B gene with hypercholesterolemia and the risk of ischemic heart disease. New Engl J Med 1998; 338: 1577-1585. 
8 Soria LF, Ludwig EH, Clarke HRG, Vega GL, Grundy SM, McCarthy BJ: Association between a specific apolipoprotein B mutation and familial defective apolipoprotein B-100. Proc Natl Acad Sci USA 1989; 86: 587-591.

9 Gaffney D, Reid JM, Cameron IM et al: Independent mutations at codon 3500 of the apolipoprotein B gene are associated with hyperlipidemia. Arterioscl Thromb Vasc Biol 1995; 15: $1025-$ 1029.

10 Pullinger CR, Hennessy LK, Chatterton JE et al: Familial liganddefective apolipoprotein B. Identification of a new mutation that decreases LDL receptor binding activity. J Clin Invest 1995; 95: $1225-1234$.

11 Rauh G, Keller C, Schuster H, Wolfram G, Zoellner N: Familial defective apolipoprotein B-100: a common cause of primary hypercholesterolemia. Clin Invest 1992; 70: 77-84.

12 Myant NB, Forbes SA, Day INM, Gallaghers J: Estimation of the age of the ancestral arginine $3500 \rightarrow$ glutamine mutation in human ApoB-100. Genomics 1997; 45: $78-87$.

13 Hansen PS, Defesche JC, Kastelein JJP et al: Phenotypic variation in patients heterozygous for familial defective apolipoprotein $B$ (FDB) in three European countries. Arterioscl Thromb Vasc Biol 1997; 17: $741-747$.

14 Hansen PS: Familial defective apolipoprotein B-100. Danish Med Bull 1998; 45: 370-382.

15 Ludwig EH, McCarthy BJ: Haplotype analysis of the human apolipoprotein $\mathrm{B}$ mutation associated with familial defective apolipoprotein B-100. Am Soc Hum Genet 1990; 47: 712-720.

16 Górski B, Kubalska J, Naruszewicz M, Lubiński J: LDL-R and apoB-100 gene mutations in Polish familial hypercholesterolemias. Hum Gen 1998; 102: $562-565$.

17 Study Group. European Atherosclerosis Society: The recognition and management of hyperlipidemia in adults: a policy statement of the European Atherosclerosis Society. Eur Heart $J$ 1988; 9: 571-590.

18 Maniatis T, Fritsch EF, Sambrook J: Molecular cloning. A laboratory manual. Cold Spring Harbor, NY: CSH Press, 1982.

19 Schuster H, Rauh G, Müller S, Keller C, Wolfram G, Zöllner N: Allele-specific and asymmetric polymerase chain reaction amplification in combination: A one step polymerase chain reaction protocol for rapid diagnosis of familial defective apolipoprotein B-100. Anal Biochem 1992; 204: 22-25.
20 Chaves FJ, Puig O, Garcia-Sogo M et al: Seven DNA polymorphism in the LDL receptor gene: application to the study of familial hypercholesterolemia in Spain. Clin Genet 1996; 50: $28-35$.

21 Motti C, Funke H, Rust S, Dergunov A, Assmann G: Using mutagenic polymerase chain reaction primers to detect carriers of Familial Defective Apolipoprotein B-100. Clin Chem 1991; 37: $1762-1766$

22 Régis-Bailly A, Visvikis S, Steinmetz J et al: Frequencies of five genetic polymorphisms in coronarographed patients and effects on lipid levels in a supposedly healthy population. Clin Genet 1996; 50: 339-347.

23 Hixson JE, Vernier DT: Restriction isotyping of human apolipoproteinE by gene amplification and cleavage with HhaI. J Lipid Res 1990; 31: $545-548$.

24 Tybjaerg-Hansen A, Humphries S: Familial defective apolipoprotein B-100: a single mutation that causes hypercholesterolemia and premature coronary artery disease. Atherosclerosis 1992; 96: $91-107$

25 Program Pol-MONICA Warszawa: Kompleksowa ocena stanu zdrowia ludności Warszawy w roku 1993 i jego zmian w latach 1984-1993. Czȩść V. Podstawowe wyniki trzeciego badania przekrojowego przeprowadzonego w 1993 roku oraz 10-letnie trendy poziomu czynników ryzyka w populacji prawobrzeżnej Warszawy (1984-1993). Instytut Kardiologii w Warszawie 1995

26 Goldstein JL, Hobbs HH, Brown MS: Familial hypercholesterolemia. in: Scriver CR, Beaudet AL, Sly WS, Valle D (eds): The metabolic and molecular bases of inherited disease. 7th edition. New York: McGraw-Hill, Inc., 1995, vol.II 1981-2030.

27 Hansen PS, Meinertz H, Jensen HK et al: Characteristics of 46 heterozygous carriers and 57 unaffected relatives in five Danish families with familial defective apolipoprotein B100. Arterioscler Thromb 1994; 14: $207-213$.

28 Rabes JP, Varret M, Sain-Jore B et al: Familial ligand-defective apolipoprotein B-100: Simultaneous detection of the $\operatorname{Arg}_{3500} \rightarrow$ Gln and $\operatorname{Arg}_{3531} \rightarrow$ Cys mutations in a French population. Hum Mutat 1997; 10: 160-163. 